\title{
Human behavior and judgment: A critical nano-foundation for the Uppsala model and international business studies
}

\author{
Jan-Erik Vahlne ${ }^{1}$ and \\ Roger Schweizer ${ }^{1}$ \\ ${ }^{1}$ Centre for International Business Studies, School \\ of Business, Economics and Law, University of \\ Gothenburg, Department of Business \\ Administration, PO Box 610, 40530 Göteborg, \\ Sweden
}

Correspondence:

R Schweizer, Centre for International Business Studies, School of Business, Economics and Law, University of Gothenburg, Department of Business Administration, PO Box 610,

40530 Göteborg, Sweden

e-mail: roger.schweizer@handels.gu.se

\begin{abstract}
Economists and researchers of decision-making and business behavior increasingly rely on findings from the field of economic psychology. We argue that, by following a similar route, knowledge of firms' internationalization is considerably enriched. The aim of this commentary is to point to the potential of including insights from research on human cognition and judgment in explaining internationalization behavior. We offer some examples relying upon commitments and knowledge development as outlined in the Uppsala model and thereby propose a conceptualization linking the nano- and micro-levels within the model.
\end{abstract}

Journal of International Business Studies (2022) 53, I549-I555.

https://doi.org/ I 0. I057/s4 I 267-022-00502-0

Keywords: human cognitive and judgment characteristics; internationalization; Uppsala model; nano- and micro-levels

The online version of this article is available Open Access

\section{INTRODUCTION}

A remaining and recurrent criticism raised against micro- or firmlevel models in the field of international business (IB), such as the Uppsala internationalization process model (henceforth, Uppsala model $^{1}$ ), is the lack of adequate inclusion of the individual's role as a core nano-foundation ${ }^{2}$ in explanations of internationalization (e.g., Coviello, Kano, \& Liesch, 2017; Foss, 2011; Kano \& Verbeke, 2015; Treviño \& Doh, 2020; Vahlne \& Bhatti, 2019; Vahlne \& Johanson, 2020; Verbeke \& Kano, 2015). Indeed, despite Aharoni's (1966) early call and empirical evidence (e.g., Calof \& Beamish, 1995; Child, Ng, \& Wong, 2002) highlighting the importance of considering managers' cognitive processes and biases, research on firms' internationalization processes has hitherto ignored human behavior in explaining internationalization decisions (Maitland \& Sammartino, 2015). We use the term human behavior to refer to the potential and expressed capacity (mental, physical, and social) of human individuals to respond to internal and external stimuli (Kagan, Bornstein, \& Lerner, 2020).
Received: 1 February 2021

Revised: 27 November 2021

Accepted: 8 December 2021

Online publication date: 26 January 2022 
The purpose of this commentary is to advance the above-outlined quest to include human behavior in explaining a firm's internationalization process. Highlighting the importance of cognitive, emotional, and social triggers as well as biases that affect managers' behavior and judgment in the Uppsala model (Johanson \& Vahlne, 1977, 2009; Vahlne \& Johanson, 2020), we offer a conceptualization linking the nano- and micro-levels (see Figure 1). We understand human behavior and judgment as nano-level phenomena of large importance in all rudiments of, for example, the Uppsala model and for IB research in general.

Drawing on insights from the field of behavioral strategy (Powell, Lovallo, \& Fox, 2011), we first offer a brief sketch on various traits of human behavior and judgment that we believe influence commitment decision-making and knowledge-development processes that drive change in the Uppsala model. We then discuss interdependencies between the nano- and micro-level phenomena of the Uppsala model's change mechanisms, for the moment leaving aside the state variables (Johanson \& Vahlne, 1977). However, as we illustrate in Figure 1, we believe that two interacting levels also define the state variables in the Uppsala model namely, capabilities and commitments/ performance. One example is the degree of commitment, where a powerful individual can affect the firm's commitment. Furthermore, we also exclude a discussion on other-level phenomena, such as macro- and meso-level. An example of a macro-level variable of interest would be the psychic distance; an interesting meso-level variable is the network positions of important competitors (Johanson \& Vahlne, 2009).

\section{NANO- AND MICRO-LEVEL INTERACTIONS IN COMMITMENT PROCESSES}

In this section, based on our general model (see Figure 1), we use the example of human behavior to exemplify our conceptualized interaction between the nano- and micro-levels for commitment processes within the Uppsala model. In the Uppsala model, an opportunity and risk management mechanism drives change (Johanson \& Vahlne, 1977, 2009; Vahlne \& Johanson, 2020). Resource allocation decisions are made when there is a reasonable positive trade-off between the expected benefits and the downside outcomes of an opportunity (Figueira de Lemos, Johanson, \& Vahlne, 2013; Johanson \& Vahlne, 1977; Schweizer, Vahlne, \& Johanson, 2010). The relationship
State Variables

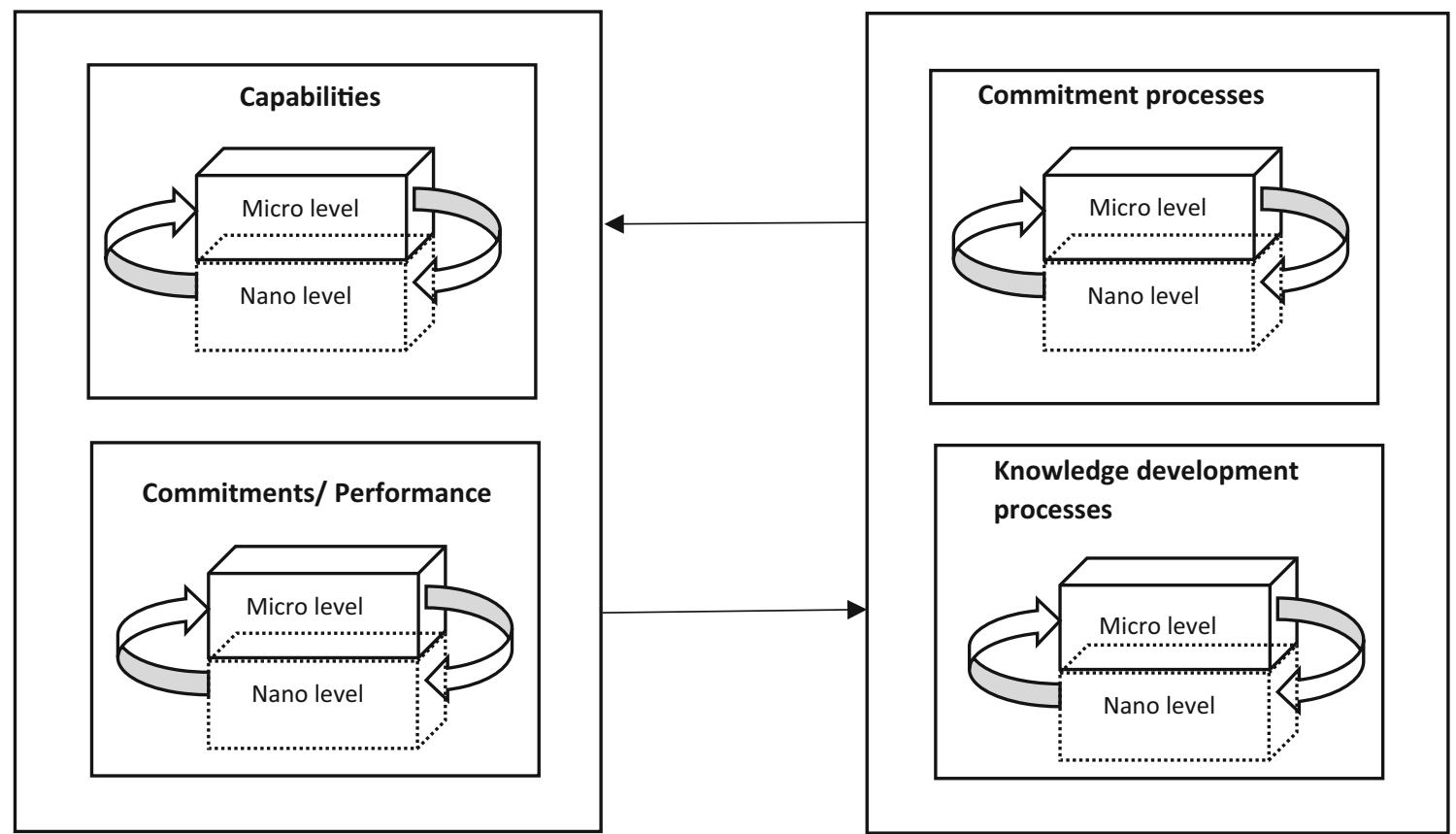

Figure 1 Nano- and micro-level interactions in the Uppsala model. Note: As Vahlne and Johanson (2017) indicated, the two change processes affect each other, though indirectly, via their impact on the state variables, in turn triggering additional change. 
between potential benefit and potential loss is a quota. We refer to the cut-off value of that quota namely, the value above which the firm commits resources to the opportunity - as the risk limit. Risk equals (even if probabilities cannot be measured) the subjectively perceived chance times that resources are at stake (cf. March \& Shapira, 1987). We believe that the quota of perceived benefits and risks often grows because learning, creation, and trust-building are continuously ongoing, the risk limit is immobile, and more opportunities gradually become attractive as most evolutionary processes are incremental. We further argue that the perception of a benefit-loss quota related to a particular opportunity is dependent on not only facts, such as the position of the focal firm and its competitive situation, but also cognitively and emotionally biased evaluations by the individuals involved in the process (George \& Dane, 2016). For example, studies in IB show that a manager's perception of differences between domestic and host market conditions affect their decisions (e.g., Armstrong, Cools, \& Sadler-Smith, 2012; Francioni, Musso, \& Cioppi, 2015).

Human behavior has a defining impact on change through intermittent decision processes related to committing/not-committing resources. Decision-makers with bounded rationality face uncertainty and goal ambiguity (Vahlne \& Johanson, 2020), which are, in turn, products of intersubjective processes attributing meaning to events (Brownlie \& Spender, 1995). Previous empirical IB studies have highlighted decision-makers' cognitive systems as explanatory factors of the firm's decision-making process (e.g., Acedo \& Jones, 2007; Sommer, 2010). Cognitive processes influence how managers acquire, process, and organize internal and external information (cf. Kozhevnikov, 2007; Smith, 2007). Cognitive processes are subject to the manager's personality (George, 2000) and are difficult to leave/change (Raffaeli, Glynn, \& Tushman, 2019).

Cultural intelligence influences the degree of local adaptation (Ang, Dyne Van, Koh, Ng, Templer, Tay, \& Chandrasekar, 2007), and agreeableness and emotional stability facilitate the acquisition of market knowledge (Chollet, Geraudel, Khedhaouria, \& Mothe, 2016). Due to high ambiguity and uncertainty in the internationalization process (Schweizer et al., 2010) and the need to be responsive to social and other environmental requirements (Gavetti, Greve, Levinthal, \& Ocasio, 2012), managers employ judgment.
A manager's goal orientation - that is, an actor's goal preferences in achievement situations that guide achievement-related behavior and task engagement (Domurath, Coviello, Patzelt, \& Ganal, 2020) and are stable over time (Button, Mathieu, \& Zajac, 1996) - influences judgment.

Emotions and moods, which are relatively immediate, transient, and flexible over time (Weiss \& Beal, 2005), play a central role in humans' cognitive processes and behaviors (George, 2000). Whereas emotions are highly intensive feelings triggered by specific internal or external stimuli (George, 2000), a mood is not directly linked to a specific event (Frijda, 1993). Therefore, a decision can be influenced not only by emotions that arise from the decision at hand (Lerner, Li, Valdesolo, \& Kassam, 2015), but also by the mood at the time a decision is made (George \& Dane, 2016).

Decisions are also influenced by experienceestablished heuristics. Using feedback loops from, for example, previous internationalization processes, a manager learns what works and what does not (Bingham \& Eisenhardt, 2011). We believe this mechanism is close to the notion of the "problemistic search" (Cyert \& March, 1963).

In line with Schneider and De Meyer (1991), who argued that strategic processes are influenced by managers' individual characteristics and group dynamics (in our model, the nano-level), the internal organizational context (in our model, the micro-level), and environmental factors (the mesoand macro-level, which we excluded from this commentary), in our conceptualization, the micro-level constitutes the context of the nanolevel processes. Hence, the micro-level context influences the deeds on the nano-level. Romanelli and Tushman (1986) pointed out that existing organizational arrangements, structures, systems, processes, and resources constrain future strategic decision-making. Another example is that performance experienced by the focal firm affects attitudes and experiences of the individuals engaged (George \& Dane, 2016). In addition, Cyert and March (1963) concluded that superior performance expectedly lowers the intensity and form of the information search. The experiences brought about by a newly appointed company president may also have a strong impact on commitment levels and the willingness to try actions outside of the present scope of ideas, such as through the application of analogical thinking (Pontikes \& Rindova, 2020). Figure 2 summarizes how we conceptualized the 


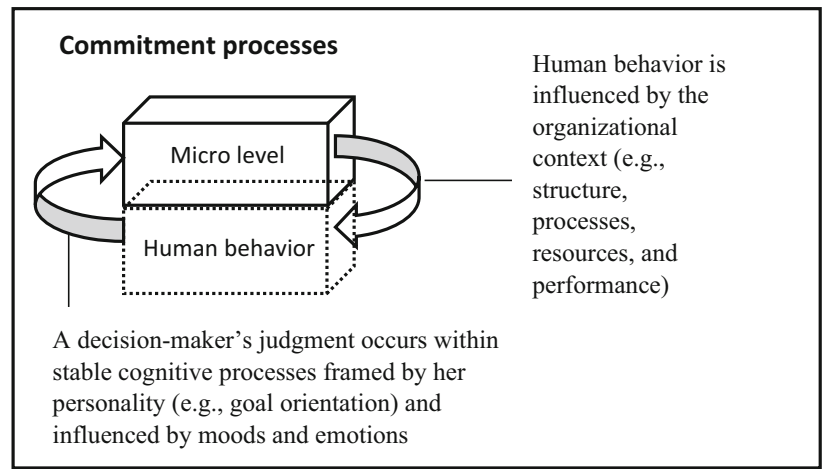

Figure 2 Human behavior and micro-level interactions in commitment processes.

nano- and micro-level interactions in commitment processes.

\section{NANO- AND MICRO-LEVEL INTERACTIONS IN KNOWLEDGE DEVELOPMENT}

The knowledge-development processes, by definition, happen at the nano-level: Individuals learn, share, and exchange knowledge, all with the intention of leading to consequences at the micro-level (Herriott, Levinthal, \& March, 1985). Human behavior influences knowledge development and its three sub-processes: learning, creation, and trust building. Learning can happen in several ways (Forsgren, 2002), yet learning by experience is the most important form of learning (Cyert \& March, 1963; Johanson \& Vahlne, 1977; Penrose, 1959). Indeed, managers' learning and their interpretations of what they learn depend heavily on previously acquired knowledge and experiences about the environment and the capabilities of both the firm and its network partners (Vahlne \& Johanson, 2017). ${ }^{3}$ In addition to prior experiences, learning is affected by biases because of absorptive capacity (Cohen \& Levinthal, 1990) and, as argued by Bingham and Eisenhardt (2011), what we learn are heuristics for selection and procedural, temporal and priority, and simplification. Relevant contextual knowledge makes it possible to integrate new knowledge and, hence, increases the absorptive capacity (Cohen \& Levinthal, 1990). The concept of absorptive capacity is applicable at both the nano- and micro-levels. In a similar vein, creation - that is, the process whereby new knowledge is developed or adjusted to be useful to the individual in his/her capacity as a manager in the business firm - is often the result of heuristics as well as subjective and intuitive processes (Vahlne \& Johanson, 2017). The creation of new knowledge is built into human beings through evolution (Koestler, 1964) and thereby occurs unconsciously as a creative process influenced by, for example, emotions (cf. Healey \& Hodgkinson, 2014). Similarly, we argue that trust building is influenced by prior experiences, personality traits, and emotions (Vahlne \& Johanson, 2021) as trust is, to some extent, a substitute for knowledge (Morgan \& Hunt, 1994; Smith, 2007).

What and how individuals learn and create depend largely on the context at the micro-level, which is the focal firm and other network actors; the context then is intentions, available resources, and level of uncertainty (Figure 3). Specifically, performance as compared with expectations may trigger an active search to be combined with one's own experiences (Kogut \& Zander, 1992; Pontikes $\&$ Rindova, 2020). Accordingly, knowledge development is not only a matter of individual or organizational processes, but can also have a collective dimension, such as the network of which the focal firm is a member (Johanson \& Vahlne, 2009). Learning occurs among all actors within the network, and knowledge learned is modified and shared. This process happens over time and with many different actors involved; the knowledge is shared through organizational learning and is subsequently aggregated to the whole network (Moen, Agarwal, \& Shah, 2020). Hence, phenomena at the two levels - nano and micro - are interdependent. The nature of that interdependence, with its temporal, individual, collective, and dynamic aspects, is an area of great relevance for future research. For example, internationalization knowledge, business knowledge, and institutional knowledge vary not only in their importance during the internationalization process (Eriksson,

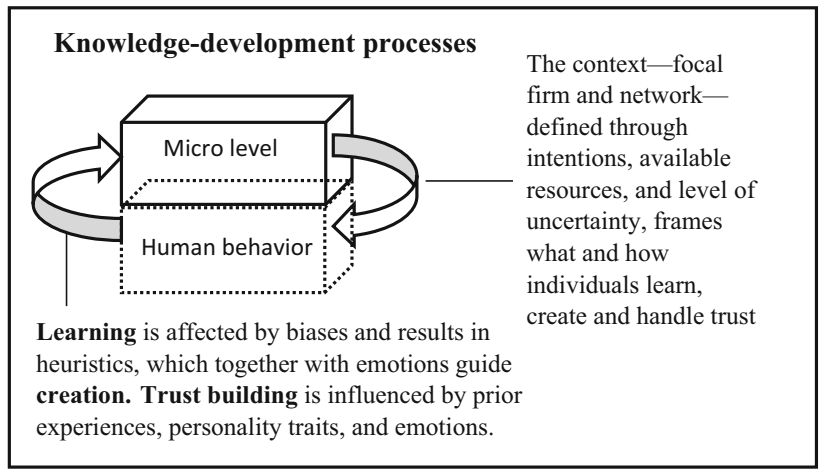

Figure 3 Human behavior and micro-level interactions in knowledge-development processes. 
Johanson, Majkgård, \& Sharma, 2000), but also in their nano- and micro-level interactions. Whereas business knowledge learning is experiential in nature, institutional knowledge is more the object of an active search (Johanson \& Vahlne, 1977).

\section{CONCLUSION FOR FUTURE RESEARCH}

Using human behavior as an example of a nanolevel constituent, this commentary offers a first conceptualization linking the nano- and microlevels for the change variables of the Uppsala model. We also leave the central state variables aside in this short commentary, hoping they will be the object of future study. The same is true for the interactions with the meso- and macro-levels. As already indicated in Figure 1, we believe that including the nano- and micro-level interactions does not give rise to changes in the basic processes and dynamics in the Uppsala model, which was developed for the aggregate micro-levels. In fact, in referring to human behavior as one example of a nano-level element, we argue that Johanson and Vahlne's (from 1977 onwards) research has consistently considered - at least implicitly - the individual's role as an important element of the Uppsala model through its critical mechanisms of learning and trust. Then again, we see an urgent need for studying the interdependency between the nanoand micro-levels of internationalization. We believe this will be a core area in future IB research, such as in explanations of inter-firm differences, especially in terms of multinationals from mature and emerging markets. Undoubtedly, other nanolevel phenomena beyond the characteristics of key individuals of the firm, such as power distribution among different stakeholder groups, should be included in studies on impacts from nano-level phenomena on micro-level internationalization behavior. Furthermore, by relating commitment decisions to the ongoing discourse in research if biases are systematic (e.g., Tversky \& Kahneman, 1974) or rarely so (e.g., Smith, 2007), future studies could link biases to the importance of a decision.

Another interesting avenue for further research is related to the criticism of the Uppsala model not being able to provide a theoretical explanation for non-linear and discontinuous dynamics of the process over time (i.e., firms' leap-frogging stages; Santangelo \& Meyer, 2017). By highlighting human behavior and other nano-level phenomena, it could be argued that a decision-maker's framing of any given situation, which is in turn based on personality and cognitive processes, might result in an incremental internationalization process, although still with disruptive outcomes. Then again, although likely a rare situation, the personal experiences of an individual (e.g., a new CEO's experiences of successful internationalization) recruited externally may lead to - at least as perceived by the focal firm - revolutionary change. To tackle interrelationship issues between nano- and micro-level phenomena, longitudinal studies are preferable as the time dimension must be explored (Vahlne \& Johanson, 2017).

\section{FUNDING}

Open Access funding provided by University of Gothenburg.

\section{NOTES}

${ }^{1}$ For a recent exposition of the evolution of the Uppsala model and its contribution to the IB literature, please see Vahlne (2020)

${ }^{2}$. Since the beginning of IB research, the microlevel is the level of the individual economic subjects, such as a firm (e.g., Johanson \& Vahlne, $1977,2009)$, but also of individuals, such as managers (e.g., Coviello et al., 2017). To distinguish between the firm and individuals, Vahlne and Johanson (2017) use the milli-micro-level for the latter. We maintain such a distinction but, advocating a metric system logic, we name the level below the micro-level the nano-level to avoid confusion (cf. Thompson \& Hart, 2006)

${ }^{3}$ We emphasize learning processes that occur between individuals and across networks, although we acknowledge that an individual's learning also affects organizational decisions and behavior (see Niittymies and Pajunen (2020) for a recent review on the role of cognition and learning in firms' internationalization) 


\section{REFERENCES}

Acedo, F. J., \& Jones, M. V. 2007. Speed of internationalization and entrepreneurial cognition: Insights and a comparison between international new ventures, exporters and domestic firms. Journal of World Business, 42(3): 236-252.

Aharoni, Y. 1966. The foreign investment decision process (Vol. 403). Division of Research, Graduate School of Business Administration, Harvard University.

Ang, S., Van Dyne, L., Koh, C., Ng, K. Y., Templer, K. J., Tay, C., \& Chandrasekar, N. A. 2007. Cultural intelligence: Its measurement and effects on cultural judgment and decision making, cultural adaptation and task performance. Management and Organization Review, 3(3): 335-371.

Armstrong, S. J., Cools, E., \& Sadler-Smith, E. 2012. Role of cognitive styles in business and management: Reviewing 40 years of research. International Journal of Management Reviews, 14(3): 238-262.

Bingham, C. B., \& Eisenhardt, K. M. 2011. Rational heuristics: The 'simple rules' that strategists learn from process experience. Strategic Management Journal, 32(13): 1437-1464.

Brownlie, D., \& Spender, J. C. 1995. Managerial judgement in strategic marketing. Management Decision, 33(6): 39-50.

Button, S. B., Mathieu, J. E., \& Zajac, D. M. 1996. Goal orientation in organizational research: A conceptual and empirical foundation. Organizational Behavior and Human Decision Processes, 67(1): 26-48.

Calof, J. L., \& Beamish, P. W. 1995. Adapting to foreign markets: Explaining internationalization. International Business Review, 4(2): 115-131.

Child, J., Ng, S. H., \& Wong, C. 2002. Psychic distance and internationalization: Evidence from Hong Kong firms. International Studies of Management \& Organization, 32(1): 36-56.

Chollet, B., Geraudel, M., Khedhaouria, A., \& Mothe, C. 2016. Market knowledge as a function of CEOs' personality: A fuzzy set approach. Journal of Business Research, 69(7): 2567-2573.

Cohen, W. M., \& Levinthal, D. A. 1990. Absorptive capacity: A new perspective on learning and innovation. Administrative Science Quarterly, 35(1): 128-152.

Coviello, N., Kano, L., \& Liesch, P. W. 2017. Adapting the Uppsala model to a modern world: Macro-context and microfoundations. Journal of International Business Studies, 48(9): 1151-1164.

Cyert, R. D., \& March, J. G. 1963. A behavioral theory of the firm. Prentice Hall.

Domurath, A., Coviello, N., Patzelt, H., \& Ganal, B. 2020. New venture adaptation in international markets: A goal orientation theory perspective. Journal of World Business, 55(1): 101019.

Eriksson, K., Johanson, J., Majkgård, A., \& Sharma, D. D. 2000. Effect of variation on knowledge accumulation in the internationalization process. International Studies of Management \& Organization, 30(1): 26-44.

Figueira de Lemos, F., Johanson, J., \& Vahlne, J.-E. 2013. Risk management in the internationalization process of the firm: A note on the Uppsala model. Journal of World Business, 46(2): $143-153$.

Forsgren, M. 2002. The concept of learning in the Uppsala internationalization process model. International Business Review, 11(3): 257-278.

Foss, F. J. 2011. Why micro-foundations for resource-based theory are needed and what they may look like. Journal of Management, 37(5): 1413-1428.

Francioni, B., Musso, F., \& Cioppi, M. 2015. Decision-maker characteristics and international decisions for SMEs. Management Decision, 53(10): 2226-2249.

Frijda, N. H. 1993. Appraisal and beyond. Cognition \& Emotion, 7(3-4): 225-231.

Gavetti, G., Greve, H. R., Levinthal, D. A., \& Ocasio, W. 2012. The behavioral theory of the firm: Assessment and prospects. Academy of Management Annals, 6(1): 1-40.

George, I. M. 2000. Emotions and leadership: The role of emotional intelligence. Human Relations, 53(8): 1027-1055.
George, J. M., \& Dane, E. 2016. Affect, emotion, and decision making. Organizational Behavior and Human Decision Processes, 136: 47-55.

Healey, M. P., \& Hodgkinson, G. P. 2014. Rethinking the philosophical and theoretical foundations of organizational neuroscience: A critical realist alternative. Human Relations, 67(7): 765-792.

Herriott, S. R., Levinthal, D., \& March, J. G. 1985. Learning from experience in organizations. The American Economic Review, 75(2): 298-302.

Johanson, J., \& Vahlne, J.-E. 1977. The internationalization process of the firm: A model of knowledge development and increasing foreign market commitments. Journal of International Business Studies, 8(Spring/Summer): 23-32.

Johanson, J., \& Vahlne, J.-E. 2009. The Uppsala internationalization process model revisited: From liability of foreignness to liability of outsidership. Journal of International Business Studies, 40(9): 1411-1431.

Kagan, J., Bornstein, M. H., \& Lerner, R. M. 2020. Human behavior. Encyclopedia Britannica. https://www.britannica. com/topic/human-behavior. Retrieved May 17, 2021.

Kano, L., \& Verbeke, A. 2015. The three faces of bounded reliability: Alfred Chandler and the micro-foundations of management theory. California Management Review, 58(1): 97-122.

Koestler, A. 1964. The act of creation. Dell.

Kogut, B., \& Zander, U. 1992. Knowledge of the firm, combinative capabilities, and replication of technology. Organization Science, 3(3): 383-397.

Kozhevnikov, M. 2007. Cognitive styles in the context of modern psychology: Toward an integrated framework of cognitive style. Psychological Bulletin, 133(3): 464-481.

Lerner, J. S., Li, Y., Valdesolo, P., \& Kassam, K. S. 2015. Emotion and decision making. Annual Review of Psychology, 66: 799-823.

Maitland, E., \& Sammartino, A. 2015. Managerial cognition and internationalization. Journal of International Business Studies, 46(7): 733-760.

March, J. G., \& Shapira, Z. 1987. Managerial perspectives of risk taking. Management Science, 33(11): 1401-1418.

Moen, M., Agarwal, R., \& Shah, S. 2020. Building industries by building knowledge: Uncertainty resolution over industry milestones. Strategy Science, 5(3): 218-244.

Morgan, R. M., \& Hunt, S. D. 1994. The commitment-trust theory of relationship marketing. Journal of Marketing, 58(3): 20-38.

Niittymies, A., \& Pajunen, K. 2020. Cognitive foundations of firm internationalization: A systematic review and agenda for future research. International Business Review, 29(4): 101654.

Penrose, E. T. 1959. The theory of the growth of the firm. Basil Blackwell.

Pontikes, E. G., \& Rindova, V. P. 2020. Shaping markets through temporal, constructive, and interactive agency. Strategy Science, 5(3): 149-159.

Powell, T. C., Lovallo, D., \& Fox, C. R. 2011. Behavioral strategy. Strategic Management Journal, 32(13): 1369-1386.

Raffaeli, R., Glynn, M. A., \& Tushman, M. 2019. Frame flexibility: The role of cognitive and emotional framing in innovation adoption by incumbent firms. Strategic Management Journal, 40(7): 1013-1039.

Romanelli, E., \& Tushman, M. L. 1986. Inertia, environments, and strategic choice: A quasi-experimental design for comparative-longitudinal research. Management Science, 32(5): 608-621.

Santangelo, G. D., \& Meyer, K. E. 2017. Internationalization as an evolutionary process. Journal of International Business Studies, 48(9): 1114-1130.

Schneider, S. C., \& De Meyer, A. 1991. Interpreting and responding to strategic issues: The impact of national culture. Strategic Management Journal, 12(4): 307-320. 
Schweizer, R., Vahlne, J. E., \& Johanson, J. 2010. Internationalization as an entrepreneurial process. Journal of International Entrepreneurship, 8(4): 343-370.

Smith, V. 2007. Rational choice: The contrast between economics and psychology. Journal of Political Economy, 99(4): 877-897.

Sommer, L. 2010. Internationalization processes of small- and medium-sized enterprises-A matter of attitude? Journal of International Entrepreneurship, 8(3): 288-317.

Thompson, J. A., \& Hart, D. W. 2006. Psychological contracts: A nano-level perspective on social contract theory. Journal of Business Ethics, 68(3): 229-241.

Treviño, L. J., \& Doh, J. P. 2020. Internationalization of the firm: A discourse-based view. Journal of International Business Studies, 0047-2506/20.

Tversky, A., \& Kahneman, D. 1974. Judgment under uncertainty: Heuristics and biases. Science, 185(4157): 1124-1131.

Vahlne, J. E. 2020. Development of the Uppsala model of internationalization process: From internationalization to evolution. Global Strategy lournal, 10(2): 239-250.

Vahlne, J. E., \& Bhatti, W. A. 2019. Relationship development: A micro-foundation for the internationalization process of the multinational business enterprise. Management International Review, 59(2): 203-228.

Vahlne, J.-E., \& Johanson, J. 2017. From internationalization to evolution: The Uppsala model at 40 years. Journal of International Business Studies, 48(9): 1087-1102.

Vahlne, J. E., \& Johanson, J. 2020. The Uppsala model: Networks and micro-foundations. Journal of International Business Studies, 51(1): 4-10.

Vahlne, J.-E. \& Johanson, J. (2021). Coping with complexity by making trust an important dimension in governance and coordination. International Business Review (forthcoming).

Verbeke, A., \& Kano, L. 2015. The new internalization theory and multinational enterprises from emerging economies: $A$ business history perspective. Business History Review, 89(3): 415-445.

Weiss, H. M., \& Beal, D. J. 2005. Reflections on affective events theory. Research on Emotion in Organizations, 1(1): 1-21.

\section{ABOUT THE AUTHORS}

Jan-Erik Vahlne is Professor Emeritus at the Centre for International Business Studies, School of Business, Economics and Law, University of
Gothenburg. He earned his PhD at the University of Uppsala in 1973. He is Dr. Hc at the University of Oulu, Finland, and has twice received the Decade Award from the Journal of International Business Studies. His research interests include management of the multinational business enterprise, internationalization, and globalization processes.

Roger Schweizer is an Associate Professor at the Centre for International Business Studies, School of Business, Economics and Law, University of Gothenburg. His research interests are international strategy issues in general and firms' internationalization processes, international entrepreneurship, the relationship between headquarters and subsidiaries, as well as mergers and acquisitions in particular.

Open Access This article is licensed under a Creative Commons Attribution 4.0 International License, which permits use, sharing, adaptation, distribution and reproduction in any medium or format, as long as you give appropriate credit to the original author(s) and the source, provide a link to the Creative Commons licence, and indicate if changes were made. The images or other third party material in this article are included in the article's Creative Commons licence, unless indicated otherwise in a credit line to the material. If material is not included in the article's Creative Commons licence and your intended use is not permitted by statutory regulation or exceeds the permitted use, you will need to obtain permission directly from the copyright holder. To view a copy of this licence, visit http://creativecommons.org/licenses/by/4.0/.

Publisher's Note Springer Nature remains neutral with regard to jurisdictional claims in published maps and institutional affiliations.

Accepted by Liena Kano, Guest Editor, 8 December 2021. This article has been with the authors for three revisions. 